\title{
The Effect of Orienteering Applications on Students' Spatial Thinking Skills in Social Studies: The Case of Turkey*
}

\author{
Turan YiĞìT ${ }^{1}$ \\ Ministry of National Education, Gazipasa \\ Primary School, Kastamonu, Turkey
}

\author{
Kadir KARATEKIN² \\ Kastamonu University, Kastamonu \\ Turkey
}

\begin{abstract}
*This study was produced from the first author's master thesis under the supervision of the second author.
${ }^{1}$ Corresponding author: Ministry of National Education, Gazipasa Primary School, Kastamonu, Turkey. trnygt.ty [at]gmail.com. ORCID: 0000-0002-7487-6246

${ }^{2}$ Prof. Dr. Kastamonu University, Faculty of Education, Kastamonu/ TURKEY. kadirkaratekin [at]gmail.com. 0RCID: 0000-00033807-7030
\end{abstract}

\section{Abstract}

Spatial thinking skills are competencies individuals will need in their lives in order to know and understand the world and to perceive the space correctly. In order for individuals to have these competencies, effective traning in the development of spatial thinking skills should occur. Spatial thinking skills can be acquired through student-centered, active learning and orienteering activities, all of which can be applied in lessons as a type of game instead of through traditional teaching methods and techniques. In this study, it is aimed to investigate the effect of spatial thinking skills on the orienteering practices of students' in primary school Grade 4 Social Studies course. The study group consists of a total of 104 students: 51 students are in the experimental group and 53 students are in the control group. All participants are in Grade 4 at a primary school in Merkez district of Kastamonu province in Turkey during the 2019-2020 academic year. Lessons were taught with activities based on orienteering practices in the experimental group, and curriculum-based instruction was conducted in the control group. In the research, one of the quantitative research methods was used as a quasi-experimental model with a pretest-posttest control group. The Spatial Thinking Skill Test (STSS) developed by the researcher was used as the data collection tool. As a result of the research, it was concluded that orienteering practices are effective in developing students' spatial thinking skills. Orienteering is recommended to be used as a teaching technique in Social Studies lessons because it is an entertaining activity that enables learning by doing, the development of multi-faceted thinking, and the transference of spatial thinking skills to daily life.

\section{Keywords}

Social Studies, Spatial Thinking Skill, Orienteering 
The rapid change in the field of science and technology has affected the field of education as well as other fields. With the change, experienced, new expectations and demands were needed in education. As a matter of fact, Namal (2019) states that many elements, from the structure of the education system to the educational processes, from the qualifications of teachers and learners to teaching methods and techniques, from tools to materials, are changing and developing according to expectations and demands. In line with this teaching in Turkey, some changes are made in the program.

Since 2005, as a requirement of the constructivist approach, the transfer of skills and values has been implemented in addition to the transfer of knowledge with education programs (Türker, 2019). It is observed that skills have become more prominent in the education system, especially since the 2000s (Mutluer, 2013). Şimșek \& Öztürk (2019) emphasized the importance of including skills in programs. In their study, they show that countries applying skills-based education can find solutions to the problems the students will encounter sooner rather than later, and that new professions that we do not even know the names of today will replace today's professions, so education programs suitable for this change will be in continuous development and skills based practices will increase. Aladağ (2015) states that, due to the rapid increase of knowledge in today's age of information, providing students with the skills that will bring them to knowledge rather than conveying information as it is should be among the main objectives of education systems, Ünlü (2011) states that the skills gained should be used in everyday life together with the school. All of these justifications in Turkey as a result of the program changes made from 1st Grade are to be given to the students in all courses up to 8th Grade believed to be 9 for each course with common skills specific skills were identified (Ata, 2015, Turan, 2018, Şimşek \& Öztürk, 2019). Spatial thinking skills are one of the skills specific to Social Studies, and they were initiated in the 2004-2005 academic year for the first time in the Social Studies curriculum (Safi, 2010). These skills aim to enable students to determine their position in daily life, to determine direction and route, and to comprehend geographical information about their location.

"Spatial thinking skills are related to Geography discipline, which mostly examines human and space relations" (Emekli, 2006, p.52). Due to the suggestion that "people will gain the skills of reading and evaluating the geographical place they live in correctly with geographical information and they will develop behavioral patterns appropriate for the place" (Öcal, 2007, p.6). For example, choosing the sun-exposed side when buying or renting a house, knowing shortcuts and safe ways to go to work or school, diversifying the cultivation of agricultural products according to regions, determining livestock activities are done with geographic knowledge and skills. Demirci (2008) explains the importance of geographical knowledge and skills with the following words:

Dams whose water is mixed into the underground after a while because they were built on karstic land, factories built but not used with the wrong location, unplanned urbanization, pollution of water resources, destruction of forests, factories that leave solid, liquid and gas wastes to the natural environment without treatment despite warnings and penal sanctions and, above all, the huge life and property losses in the earthquake and floods every time, yes, all 
Yiğit, T,; Karatekin, K.(2021). The Effect of Orienteering Applications on Students' Spatial Thinking...

these are just some examples of how much importance is given and geographical knowledge in real life how it is applied to Geography in Turkey. (p.3)

The United States national geography standards define a person who has received geographic information education as a person who can see the world spatially (Mohan, Mohan \& Uttal, 2014). According to Öcal (2007) "A natural spatial knowledge is constantly included in geographical information" (p.7). Geographical information has an important function in individuals' creating a world perception towards different places, regions and cultures, and developing projects for the environment they live in by making spatial analyzes (Gençtürk, 2013). Geographical information is taught at different grade levels in schools. The course in which the knowledge and skills of the discipline of Geography in primary and secondary school levels are taught is a Social Studies course. Spatial thinking skill emerges as an important factor in the teaching of geography-content subjects, which constitute an important part of the content of the Social Studies course, known as a multi-disciplinary course (Ablak, 2019).

This skill, which we often use without even realizing it, has become a part of our daily life. For example, spatial thinking skills are used when organizing the library in our home, placing items in the room, preparing our luggage for travel, crossing the road, going from one place to another, at home, at school, at work, on the street, in short, in all areas of life. For this reason, spatial thinking skills are among the basic life skills that should be acquired by students. According to Sönmez (2010), spatial thinking skills are very important for students not to have problems with the environment they live in and to adapt to the environment in the future. This importance has been clearly emphasized in the 2018 Social Studies Lesson Curriculum with the special purpose of "It is aimed to explain the interaction between humans and the environment by recognizing the general geographical features of the world in which they live and to develop their space perception skills " (Ministry of National Education [MoNE], 2018, p.7).

Spatial thinking is not only about being aware of the elements in the environment and learning their quality and quantity (Gençtürk, 2013). A student who has developed spatial thinking skills can also read spatial drawings, make various drawings of the space, and make comparisons. It is possible to grasp the relationship between objects more easily, and accordingly, it is possible to explain its relations with geographical concepts, causes and consequences (Sönmez, 2010). Spatial thinking skill helps the individual to understand what is happening around him. In short, in today's world, it is important to gain spatial thinking skills to people who live together with space in every phase of life (Aktürk, Yazıcı \& Bulut, 2013).

It is observed that individuals who have not developed spatial thinking skills experience various problems in daily life, especially a defect in describing the way and direction (Öcal, 2007). In addition, it is inevitable for a person who cannot perceive the concept of direction to experience difficulties in daily life, as it will be difficult for a person to predict which route to follow while going to work, and which street or street to turn to (Taş, 2006). This is because "The place is the place 
where all human activities are realized and all experiences are lived" (Tümertekin \& Özgüç, 2019, p.60).

In 2004 It was the first time that special thinking skills curriculum were located in Social Studies curriculum and it was updated in 2018. In Grade 4 primary school Social Studies lessons the spatial thinking skill is aimed to be directly acquired in the learning area of "People, Places and Environments". A total of 6 acquisitions are included in this learning area and 20 lesson hours are allocated to the learning area. Despite this, there are problems in the acquisition of the spatial thinking skills in the Social Studies curriculum in general and of particular spatial thinking skills.

In already conducted research, it was stated that factors such as age, intelligence, time, lack of course materials, students' socio- economic status and their interest in lessons, class size, and gender have negative effects on the acquisition of skills in the Social Studies course curriculum (Akgül, 2006, Kan, 2006, Karatekin, 2006, Alataş, 2008, Köşker, 2012, Akmehmetoğlu, 2014, Baloğlu Uğurlu \& Aladağ, 2015, Şahin \& Güven, 2016, Taşdemir, 2016). In addition, it was observed that teachers do not know enough methods and techniques in Social Studies teaching, they do not use a systematic and special method, and they need more in-service training (Kan, 2006, Safi, 2010, Baloğlu Uğurlu \& Aladağ, 2015).

Again, in the research it has been determined that traditional methods such as direct instruction, question-answer and discussion are the methods and techniques most used by classroom teachers in social studies course (Akgül, 2006, Şahin \& Güven, 2016). In a study named The effect of teaching the subject of direction and finding methods according to multiple intelligence theory on students success at the 4th class of primary school it has been concluded that classroom teachers are not sufficient in teaching the subject of the direction in which the ability to perceive the space in social studies lesson is involved (Karatekin, 2006). Furthermore, Karatekin, Sönmez \& Kuş (2010) stated that the teachers complained about the excessive class size, the difficulty in obtaining the course materials and the insufficient duration in the teaching of direction.

However, the teachers stated that the activities in the textbooks remained in the classroom and that the activities could not be associated with abstract and daily life. In addition, they stated that the teachers felt insufficient in teaching the subject of direction since they are not subject matter teachers. Merç (2017) stated that students have difficulties in transforming the knowledge they learn into skills and using them in real life due to trying to teach the subjects such as location, sketch, direction and route determination, and the use of compass in the classroom, which are included in the spatial thinking skill. Öcal (2009), on the other hand, stated that although the acquisitions related to space are included in the social studies program, spatial thinking skill is not sufficiently understood by teachers. It also teacher of spatial thinking skills related information is insufficient, and the program has not been prepared with overlapping of spatial thinking skills acquisition for spatial thinking skills involved and the lack of studies on learning space. 
The transition from teacher-centered structure to student-centered structure with the reflection of the changes and developments experienced in today's curriculum makes it necessary to use functional methods and techniques in social studies lesson as in other lessons. However, the perception of the social studies course, which includes subjects and concepts related to life, as a verbal lesson causes the subjects to be treated by traditional methods such as direct instruction and question-answer by classroom teachers (Doğan, 2004, Akgül, 2006, Şahin \& Güven 2016). However, it requires the use of different teaching methods and techniques for students' learning characteristics and learning styles to be different from each other and to enrich teaching (Akgül, 2006, Avcl, 2013). One of the methods that should be used in education, especially at the primary school level, is the teaching method with games. According to Torun \& Duran (2014), the game method used as an active teaching method has taken its place in education as a teaching method that contributes to both physical and mental development of children. Uzuner (2019) states that play mediates children to reach new skills and functions, that children gain experience with play, and that what is learned is transferred to new situations.

The game provides the child with the opportunity to research their environment, recognize objects and solve problems. In this way, the child learns many concepts such as size, shape, color, size, weight, volume, measurement, counting, time, space, distance, space, and many mental processes such as matching, classification, sorting, analysis, synthesis and problem solving. (Koçyiğit, Tuğluk, \& Kök, 2007, p.336)

In recent years in Turkey and in terms of achieving the intended outcomes and skills of the widespread sport of orienteering in the world, orienteering can be used in lessons as a kind of game (Tanrıkulu, 2011, Avcl, 2013, Pouya, Demir \& Demirel, 2017). It is also thought that spatial thinking skills can be gained by students in a more enjoyable and permanent way through orienteering (Avcl, 2013). It is seen that the sport of orienteering, which provides the opportunity to practice by using geographic skills such as using maps, determining directions, locating and using a compass, and to associate the learned skill with daily life, that it contributes to the development of many skills in students (Pouya, Demir \& Demirel, 2017).

Avcl (2013) suggests that" Orienteering provides spatial perception skills, environmental awareness, living environment recognition, like winning to do work and use of direction concepts in the field, which means that many important skills and knowledge are gained from this sport" (p.4). Tanrıkulu (2011) states that orienteering can be applied from primary education to university and will help gain geographic skills. Köşker (2012) made the route of teacher survey, map, chart reading and drawing skills can be improved with orienteering event b are thereby in their classrooms of teachers who obtain this application skills can easily implement the orienteering events and children implies that may help the development of spatial skills.

MoNE, Teacher Training and Development Headquarters, Turkey Orienteering Federation and Mountaineering Federation of Turkey among the teachers in the school official attached to the Ministry of Education, 2023 Educational Vision to contribute to the objectives in line with professional and personal development, 
improving the social and athletic skills, children's problem-solving skills a cooperation protocol to improve decision-making skills was signed on 15 May 2019. It was stated that after the protocol, trainers of trainers on orienteering will be started for teachers in in-service training institutes, and the trainings will be fully applied and activity-based. It is also stated that content and activity books will be prepared and put into online and mobile services The introduction of orienteering sports to teachers in cooperation with official institutions, the inclusion of orienteering activities in vocational training seminars at the beginning, between and at the end of the semester, and its participation in in-service training seminars show that orienteering can be used in lessons as a teaching technique in the future.

As a result of the literature review, there are very few studies, domestically and internationally, which investigate the effects of orienteering practices on spatial thinking skills. In a study titled Improved mental representation of space in beginner orienteers it was found that orienteering has positive effects on spatial thinking skills (Notarnicola et al., 2012). Apart from this study, the studies obtained as a result of the literature review about spatial thinking skills are as follows: Lee (2005), Öcal (2007), Huynh (2009), Safi (2010), Jo (2011), Kim (2011), Merç (2011) Özdemir (2011), Aktürk (2012), Lee \& Bednarz (2012), Baloğlu Uğurlu \& Aladağ (2015), Merç (2017), Sönmez (2019).

Studies about orienteering are conducted by Özcan (2006), Ateş (2007), Karaca (2008), Tanrıkulu (2011), Avcı (2013), Tuna \& Balcı (2013), Vukadinović, Juhas \& Kozoderović (2015), Selanik Ay \& Yavuz (2016), Akman (2017), Pouya, Demir \& Demirel (2017), Uzuner (2019).

Therefore, the current study is important because it is the first study to demonstrate the effect on spatial thinking skills of orienteering in Turkey. The aim of this study is to reveal the effect of orienteering practices as a teaching technique with games on 4th grade students' spatial thinking skills. For this purpose, responses to the following questions are sought.

1. Do the pre-test success scores of the Spatial Thinking Skills Test of the students participating in the study differ according to the variable of the group (Experimental Group 1, Experimental Group 2, Control Group 1, Control Group 2)?

2. Do Spatial Thinking Skill Test success scores of students in the Experimental Group differ according to the measurements (pre-test post-test)?

3. Do the Spatial Thinking Skill Test success scores of students in the Control Group differ according to the measurements (pre-test post-test)?

4. Do the post-test success scores of the Spatial Thinking Skill Test of students differ according to the group (Experimental Group and Control Group) variable?

5. Does gender variable have any effect on the Spatial Thinking Skill Test posttest success scores of students in the Experimental Group and Control Group? 


\section{Methodology}

\section{Model of the Research}

In this study, in which the effect of orienteering practices in Social Studies lesson about the spatial thinking skills of primary school students in Grade 4 was wanted to be determined, a quasi- experimental model with pre-test and post-test control group was used. According to Ekiz (2013) "Experimental method is a research method used to determine cause-effect relationships between variables by examining any event, phenomenon, object, subject and agent, and to compare and measure results" (p.109). "The quasi-experimental method is the method in which the experimental and control groups are placed in a way other than random distribution. In this method, the experimental group and the control group are selected without random assignment, pre-test and post-test are applied to both groups, the experimental process is performed only on the experimental group" (Çepni, 2014, p.123).

Two experimental and two control groups were formed in this study. The reason for this is to demonstrate the effect of the independent variable on the dependent variable more strongly and to ensure external validity by keeping the sample large. The independent variable of the research is teaching with orienteering practices, and the dependent variable is spatial thinking skills.

Table 1

Research pattern

\begin{tabular}{|c|c|c|c|c|}
\hline Groups & Branches & Pre Test & Application & Post Test \\
\hline $\begin{array}{l}\text { Experimental } \\
\text { group }\end{array}$ & $\begin{array}{l}4 / \mathrm{A} \\
4 / \mathrm{C}\end{array}$ & STST & $\begin{array}{l}\text { Orienteering } \\
\text { Applications }\end{array}$ & STST \\
\hline Control Group & $\frac{4 / D}{4 / E}$ & STST & Program Based Teaching & STST \\
\hline
\end{tabular}

STST was applied as a pre-test without applying any teaching model to the Experimental Groups and Control Groups, therefore, the groups were formed according to the quasi-experimental method. Subsequently, the subjects included in the "People, Places and Environments" learning area and including the first three orienteering applications within the scope of the Social Studies course were given to the students in the Experimental group. The control group was taught by classroom teachers using curriculum-based education. At the end of the 3 week process, STST was applied to the experimental and control groups as a post-test.

\section{Working Group}

The study sample from the Kastamonu province in Turkey were studying in a primary school attached to the Central district. The study sample were from Grade 4 in classes 4/A, 4/C, 4/D and 4/E so there was a total of 104 students who participated. Proper case sampling was used in the research, including easily accessible individuals in working groups is a suitable case sampling (Ekiz, 2013). The reason for choosing the appropriate case sample in the research were related to the type and physical facilities of the school where the researcher works 
which are suitable for research; being easily accessible to students who wish to be included in the study process; and easily following the process from start to finish. In the formation of the study group, attention was paid to ensure the groups are equal to each other, and Experimental Groups and Control Groups were formed with unbiased group assignment. The pre-test results of the groups are presented in the table below.

Table 2

Descriptive Data-On Spatial Thinking Skills Test Pre-Test Scores

\begin{tabular}{lllll}
\hline Groups & Group Names & $N$ & $\bar{X}$ & Ss \\
\hline 4 / A & Experiment 1 pre-test & 28 & 9.39 & 3,823 \\
\hline 4 / C & Experiment 2 pre-test & 23 & 8,60 & 2,606 \\
\hline 4 / D & Control 1 pre-test & 28 & 11,28 & 3,720 \\
\hline 4 / E & Control 2 pre-test & 25 & 8,80 & 2,943 \\
\hline
\end{tabular}

\section{Preparation of Pactice Materials}

Before preparing the practise materials, the researcher received a 30-hour inservice orienteering training given by the MoNE, and learned how to prepare and apply the materials.

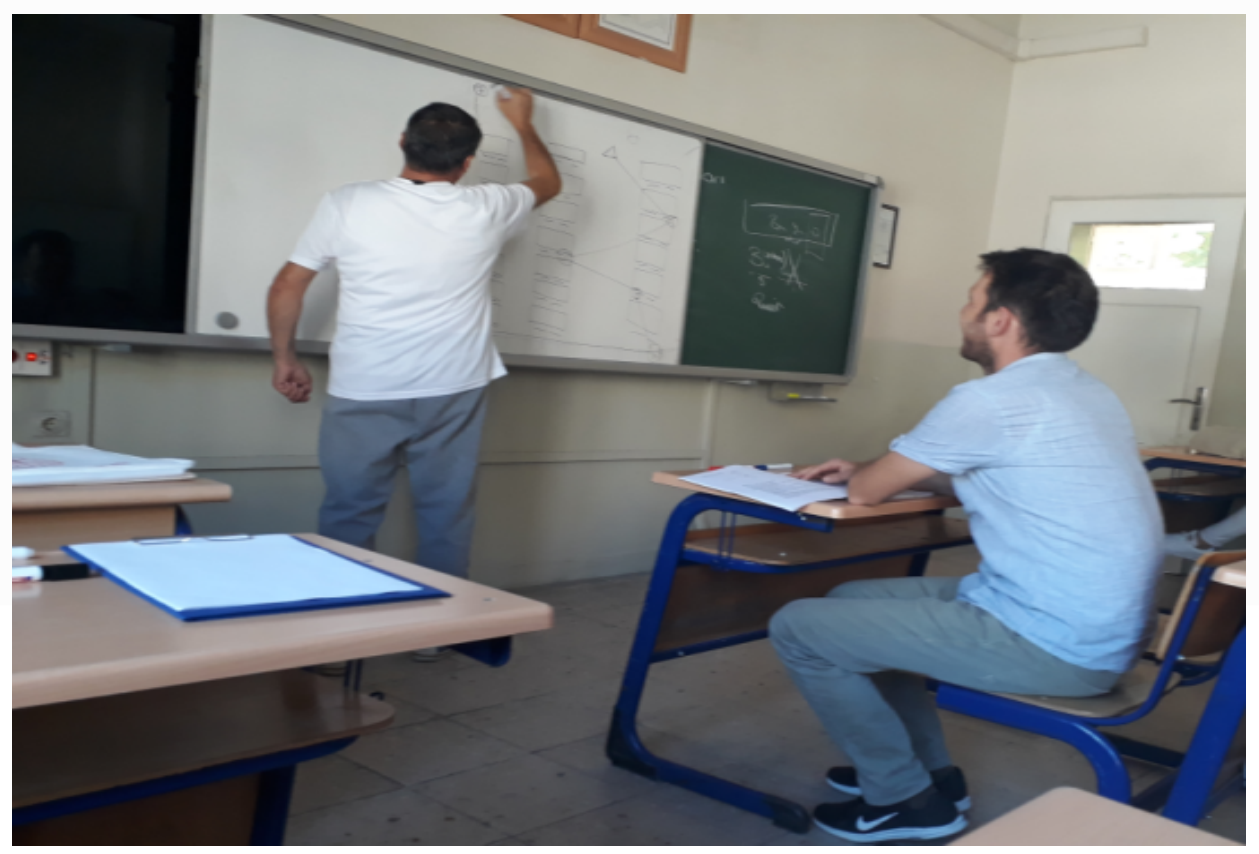

Figure 1. In -service orienteering training 
Yiğit, T.; Karatekin, K.(2021). The Effect of Orienteering Applications on Students' Spatial Thinking...

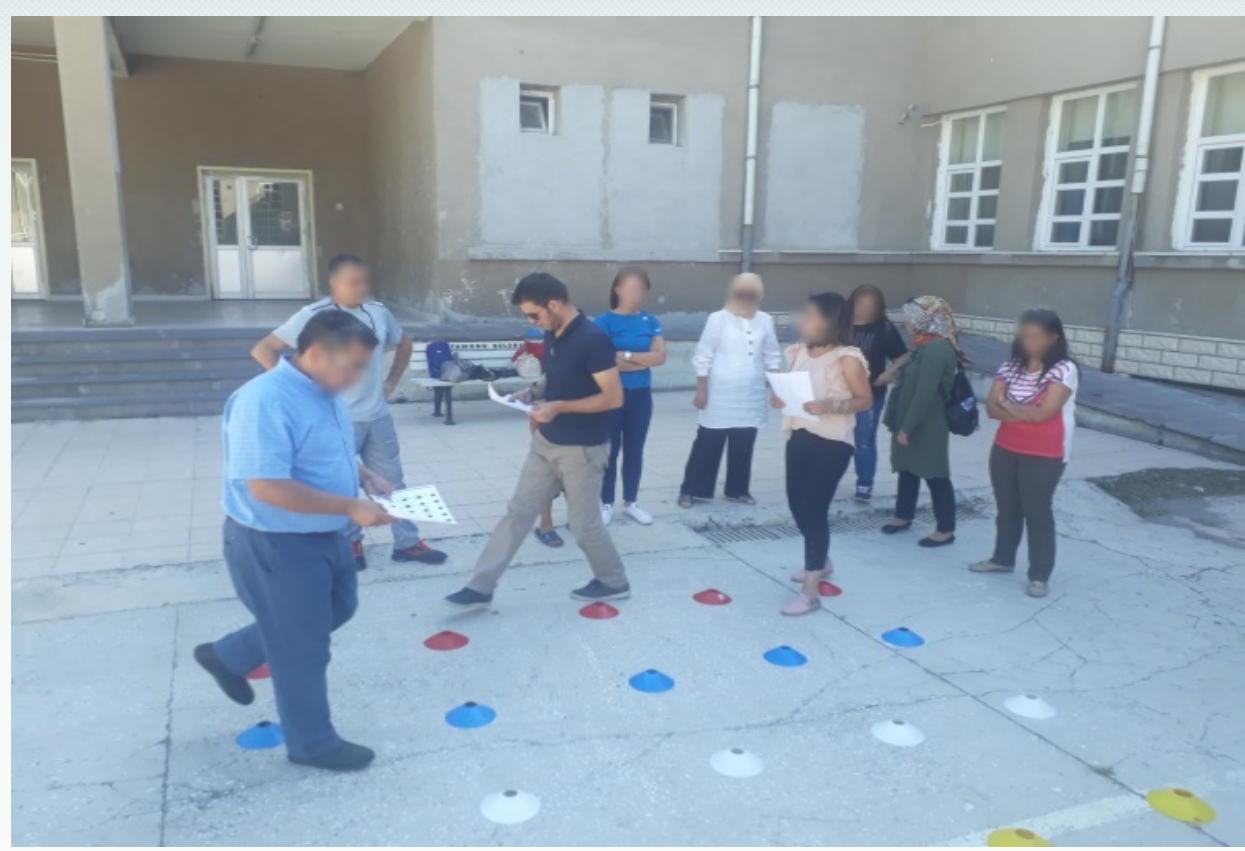

Figure 2. In -service training orienteering practices

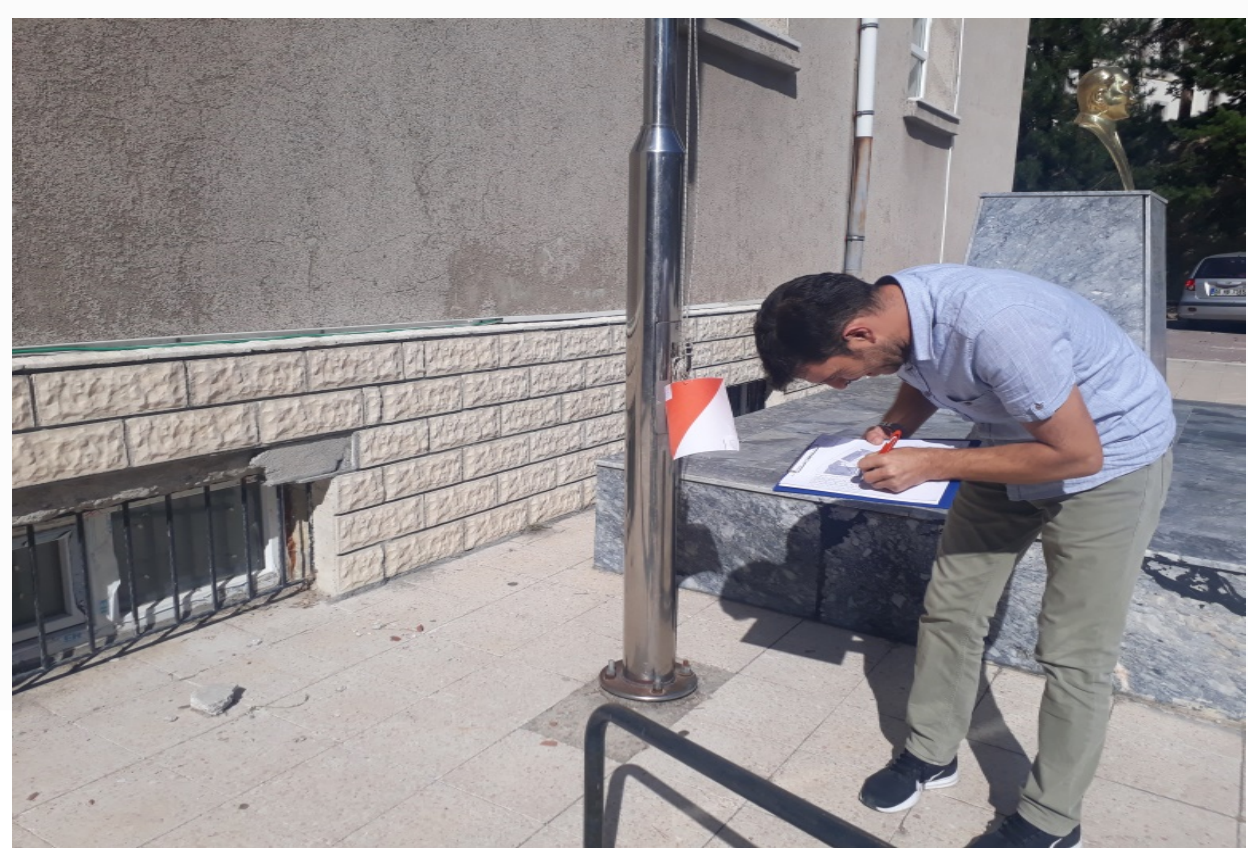

Figure 3. In -service training orienteering practices 


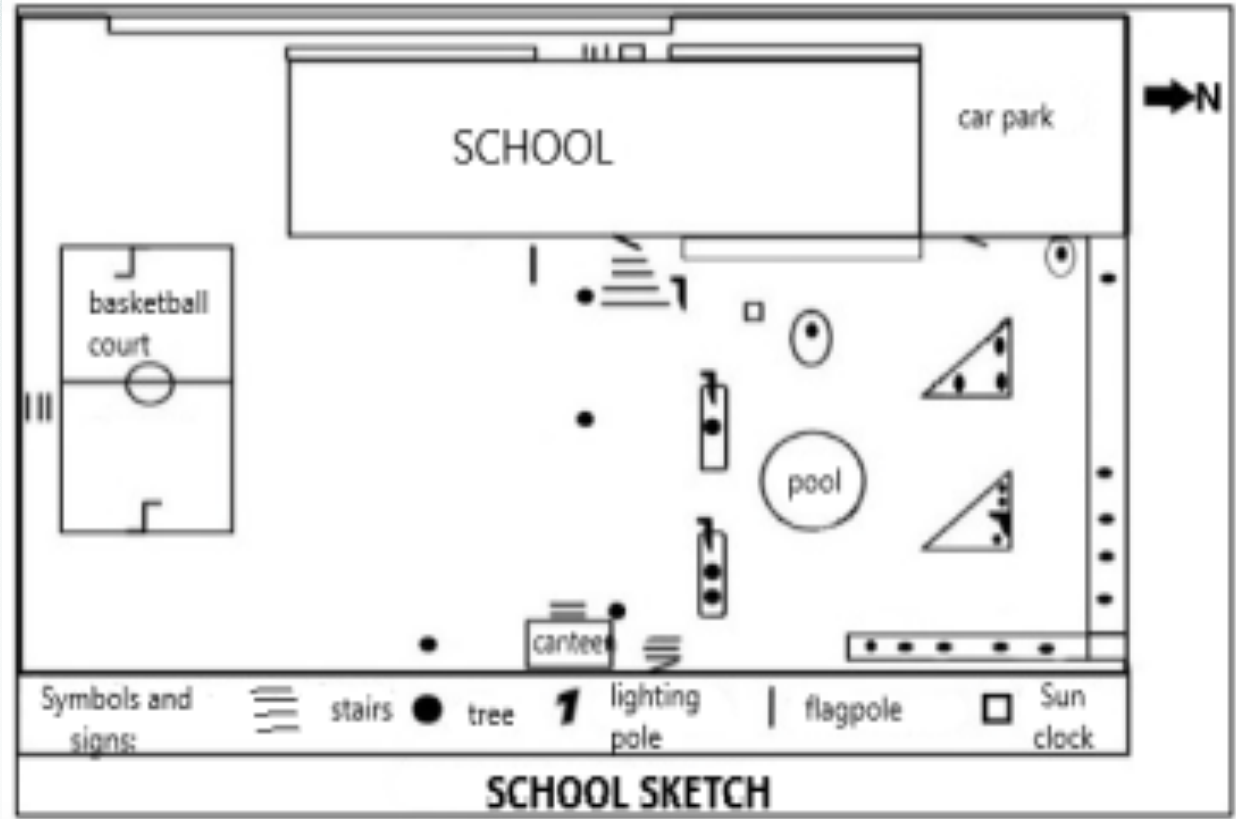

Figure 4. School sketch created by the researcher in in-service orienteering education

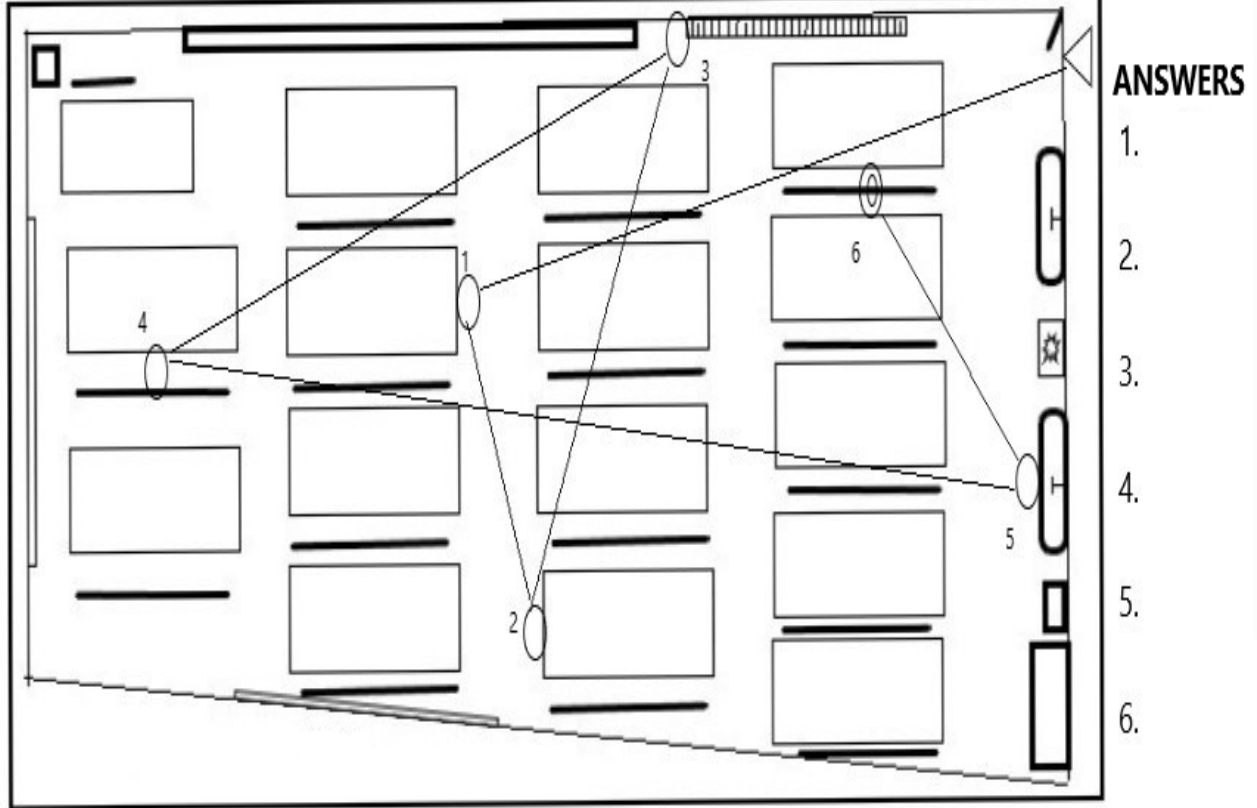

Figure 5. Class sketch and target points created by the researcher in in-service orienteering training.

STST data collection tool prepared by the researcher was used to determine the spatial thinking skills of the experimental and control groups.

\section{Data Collection Tools}

In the 4th grade lesson from the Social Studies learning area "People, Places and Environments" the following section is to be used for the preparation of orienteering practices materials: "Makes inferences about the location of any place 
in its environment, Draws the sketches of the places used in his daily life, Distinguishes the natural and human elements in his / her living environment". The purpose of selecting these skill acquisitions is that the first three acquisitions are in the field of learning "People, Places and Environments" where spatial thinking skills can be directly attended to, for students to both gain spatial thinking skills and be achieved by orienteering practices. The students were given 2 lesson hours of orienteering training in free activity lessons before the practice. This training covered what orienteering is, what it is used for, and the terms of orienteering. The materials to be used were explained, and simple practice were made under the guidance of the researcher in order to provide background information in the activities. While the researcher was preparing the activities related to each acquisition, the resources prepared for students, such as printed and visual publications, the internet resources about orienteering were scanned and activity forms suitable for the students' levels were prepared. Worksheets were also prepared with the activities. During the course of the lesson, the students were asked to follow the instructions given on the playing cards while performing the activities and write the information requested from them in the relevant sections on the blank spaces on the playing cards. Prepared events, playing cards and orienteering specialists worksheets, Classroom and Social Studies teachers, and academics in Social Studies education examined the necessary corrections and the incremental sooner was made.

Spatial thinking skill test. The following test development steps of Turgut \& Baykul (2014) were followed in the development of the spatial thinking skill test:

1. Determination of test purpose

2. Determining the properties to be measured

3. Writing the items

4. Review of substances

5. Preparation and application of trial form

6. Scoring the application results, item analysis and item selection

7. Formation of the final test and its statistics. (p. 215 )

Determination of test purpose. With the STST, it is aimed to examine the effect of orienteering practices on the spatial thinking skills of students in Social Studies teaching.

Determining the properties to be measured. In determining the content of the STST and the features to be measured, a literature review occurred and a conceptual framework related to spatial thinking skill was introduced. As a result of the literature review, from the concepts defined about spatial thinking skill, the concepts that can be learned by primary school students in Grade 4 were selected. Golledge, Marsh \& Battersby (2008) stated that the concepts of location, distance, direction, shape, symbol, border, connection, distribution, pattern, reference frame, coordinate-grid, region, and map can be learned. The characteristics that are desired to be measured in spatial thinking skill are formed in three basic dimensions as follows. 
Table 3

The Concepts Measured In the STST

\begin{tabular}{lll}
\hline & $>$ Spatial & $>$ Mental Rotation \\
\cline { 2 - 3 } Visualization & \\
\cline { 2 - 3 } Spatial Thinking Skill Orientation & $>$ Finding Location \\
\cline { 2 - 3 } & $>$ Spatial Relations & $>$ Location \\
& $>$ Distance \\
& $>$ Coordinate \\
& $>$ Impact \\
& $>$ Symbols and Signs \\
& $>$ Revealing Spatial Structures \\
\hline
\end{tabular}

Spatial visualization is the ability to mentally manipulate, rotate, twist or invert pictorially presented visual stimuli. (McGee, 1979, as cited in Lee \& Bednarz, 2009, p.184)

\begin{abstract}
Spatial orientation involves the comprehension of the arrangement of elements within a visual stimulus pattern, the aptitude for remaining unconfused by the changing orientations in which a configuration may be presented and the ability to determine spatial relations in which the body orientation of the observer is an essential part of the problem. (McGee, 1979, as cited in Lee \& Bednarz, 2009, p.184)

Finally, in the spatial relations include abilities to recognize spatial distributions and spatial patterns to connect locations, to associate and correlate spatially distributed phenomena, to comprehend and use spatial hierarchies, to regionalize, to orientate to real-world frames of reference, to imagine maps from verbal descriptions, to sketch map, to compare maps, and to overlay and dissolve maps. (Golledge \& Stimson, 1997, p. 158, cited in Lee \& Bednarz, 2009, p. 185)
\end{abstract}

An item pool of 34 items were created and the items were associated with the dimensions of spatial thinking skills. Expert opinion was then sought. As a result of the examination by orienteering experts, classroom teachers and Social Studies teachers, and two academics who are experts in the field of Social Studies education, the necessary corrections and improvements were made and the spatial thinking skills test was finalized before the pre- application. In the Grade 4 Social Studies lessons, there were three outcomes $\backslash$ thought to be given by orienteering applications which belong to the "People, Places and Environments" learning area. Care was taken by the researcher to create an equal number of questions for each skill acquisition.

Writing the items. Studies on spatial thinking skills were used to create the items to be included in the measurement tool. As a result of the literature review, the tests prepared by Lee \& Bednarz (2012) and Sönmez (2019) were examined, and these tests were used in the creation of some question items. In addition, the resources in the printed and visual materials of the Orienteering Federation and Ministry of Education General Directorate of Teacher Training and Development were also used. A draft interview form with 34 questions was prepared to measure each concept mentioned above in the part of determining the characteristics to be measured by the spatial thinking skill test. In order to determine the comprehensibility and usefulness of the questions, a pre-application was made before the pilot application with groups of 10 students studying in the 4 th grade of primary school outside the experimental and control groups and also 
from the 5th grade of a secondary school in the central district. After the preapplication, a semi-structured interview was held with the students who formed the groups and it was aimed to determine the deficiencies of the prepared interview form. As a result of the evaluations made, the expressions in some items were simplified and the distractors in some items were also regulated.

Review of substances. Issues such as the draft interview form prepared with 34 questions, having the quality to meet the skill considered to be measured, being expressed in plain language, and not having spelling mistakes were examined again.

Gelbal (2013) states that there should be three features in measurement tools: validity, reliability and usability. Çepni (2014) suggests validity is to explain how much the findings reflect the subject under investigation; and reliability means that it is used to explain how much the findings can be repeated. Some studies have been done in order to ensure the validity and reliability of the prepared interview form. In order to ensure the validity, which means measuring the quality to be measured correctly without being confused with other qualifications, the opinions of two Faculty members and two Social Studies teachers who are experts in this field were consulted. In addition, the opinions of an expert who is both a Social Studies teacher and an orienteering 2 nd level trainer were consulted regarding the suitability of the questions in the test for orienteering practices. As a result of the examination of the items during the interviews, necessary corrections were made for some items. In determining the reliability of the measurement tool, techniques such as Test-retest reliability, Parallel form reliability, Two-half-test reliability, Kuder-Richardson 20 and Cronbach-Alpha reliability, item total score correlation, and standard error of measurement are preferred (Büyüköztürk, 2007). In determining the reliability of this measurement form, the KR-20 reliability coefficient was calculated and the KR-20 reliability coefficient was found to be 0.777 .

Preparation and application of trial form. The draft interview form prepared was applied to 120 students attending the 5th grade of a secondary school in Kastamonu city Center district. Before the pilot application, which did not have any time limitation, students were informed about the purpose, duration and content of the test, and it was emphasized that solving the questions sincerely would contribute to the science of the study.

Scoring application results, item analysis and item selection. For the analysis of the data obtained from the pilot application, the item analyzes consisting of the discrimination index of the questions and the item difficulty index were carried out with the help of the TestAn Analysis program. According to the analysis results of the test, in our measurement tool consisting of 34 questions, between questions 6 and 12 with item discrimination indexes below 0.30 , it was seen that the 6 th question could not be corrected, and the 12th question should definitely be removed from the test. Consequently, these questions were excluded from the test. The distractors of the 11th question, whose item distinction index was 0.233 , were corrected, and the 21 st question, which came out 0.219 , was made to be more understandable and put into the measurement tool. Özçelik (2010, 
p.180) states that "If item discrimination indexes are 0.19 or less, the item cannot be accepted, and the item between $0.20-0.29$ should be corrected". The item difficulties of the remaining 32 questions consist of easy, medium and difficult questions, and there are no very easy and very difficult items.

Final test creation and statistics. As a result of the analysis, the item selection was made based on the item difficulty and item discrimination values in the final version of the test, which consisted of 32 items. The average difficulty value of the test was found to be 0.475 . Gelbal (2013) states that the inclusion of mediumdifficulty questions in tests plays a role in increasing reliability. As a result of the pilot applications, the item difficulty index and item discrimination index values were examined, and the items with item difficulty index between 0.29 and 0.71 were taken into consideration, and questions with item discrimination index of 0.29 and above were preferred. The average difficulty of the final test close to 0.50 indicates that it fits the ideal test qualities.

The average difficulty of the test results of the material analysis at 0,475 mean discriminant value was determined to be 0.461 . Çepni (2014) stated that the first condition to be met in scientific studies is reliability. One of the techniques used in determining the reliability for this purpose is KR-20 reliability. For the reliability coefficient of the final test prepared, KR-20 reliability coefficient was calculated using the TestAN analysis program. Accordingly, the KR-20 reliability coefficient of the final test was found to be 0.777. According to Büyüköztürk (2007), the reliability coefficient calculated for a test is 0.70 and above, which is generally sufficient for the reliability of the test scores.

\section{Data Analysis}

The data in the study were obtained from the STST. In order to measure the spatial thinking skills of the students, the spatial thinking skill test consisting of 32 questions created by the researcher was used. The test formed before and after the application was applied to the Experimental Groups and the Control Groups. For the analysis of the data obtained from the test, one-way analysis of variance (ANOVA) and t-test for unrelated groups were performed using the SPSS.22 package program.

\section{Findings}

In this section, the findings of orienteering based aplications and program based teaching in the development of spatial thinking skills of primary school students in Grade 4 are included. The obtained data was explained and interpreted in the form of tables. 
Yiğit, T.; Karatekin, K.(2021). The Effect of Orienteering Applications on Students' Spatial Thinking...

Table 4

One-Way Analysis of Variance and Tukey Test for the Difference of the Spatial Thinking Skill Test Pre-Test Success Scores of Primary School Students in Grade 4 According To the Groups

\begin{tabular}{lllllll}
\hline & $K T$ & $S d$ & $K O$ & $F$ & $p$ & $\begin{array}{l}\text { Difference } \\
\text { Tukey }\end{array}$ \\
\hline Between Groups & 119,350 & 3 & 39,783 & 3,534 &, $018^{*}$ & $3-2$ \\
\hline In Groups & 1125,871 & 100 & 11,259 & & & $3-4$ \\
\hline Total & 1245,221 & 103 & & & & \\
\hline
\end{tabular}

According to Table 4, a one-way analysis of variance (ANOVA) was conducted to determine whether there is a significant difference between the pre-test achievement scores of primary school students in Grade 4 compared between the Experimental Groups and the Control Groups. As a result of the analysis, a significant difference was observed between the groups $[F(3-100)=3,534 ; p$ $<0.05]$. A Tukey test was conducted to determine between which groups the difference occurred.

According to the test results, the spatial thinking skill test pre-test average of students in Control Group 1 was $(\overline{\mathrm{X}}=11.28)$ and Experimental Group 2 students 'spatial thinking skill test pre-test success scores was $(\bar{X}=8.60)$ and Control Group 2 students' spatial thinking skill pre-test success showed a significant difference in favor of Control Gruop 1 group students between the mean scores ( $\bar{X}=8.80)$. According to these findings, it can be said that the spatial thinking skills of the Experimental Group 1, Experimental Group 2, and Control Group 2 before the application were equivalent to each other, and the Control Group 1 students had higher spatial thinking skills compared to the other groups.

Table 5

Descriptive Data-On STST Pre-Test Success Scores

\begin{tabular}{lllll}
\hline Groups & Group Names & $N$ & $\bar{X}$ & Ss \\
\hline 1 & Experiment 1 pre-test & 28 & 9.39 & 3,823 \\
\hline 2 & Experiment 2 pre-test & 23 & 8,60 & 2,606 \\
\hline 3 & Control 1 pre-test & 28 & 11,28 & 3,720 \\
\hline 4 & Control 2 pre-test & 25 & 8,80 & 2,943 \\
\hline
\end{tabular}

Table 6

The T-Test Results for the Difference of the STST Pre-Test Success Scores of Primary School Students in Grade 4 Compared To the Experimental-Control Groups

\begin{tabular}{lllllll}
\hline Group & $N$ & $\bar{X}$ & $S$ & $s d$ & $T$ & $p$ \\
\hline $\begin{array}{l}\text { Experimental } \\
\text { group }\end{array}$ & 51 & 9,03 & 3.3224 & 102 & $-1,586$ &, 116 \\
\hline Control group & 53 & 10.11 & 3,5715 & & & \\
\hline
\end{tabular}

When the Experimental Groups and Control Groups were combined as a single Experimental Group and a single Control Group, there was no significant difference 
between the mean scores of the spatial thinking skill test pre-test from primary school students in Grade 4 compared to the Experimental Groups and Control Groups [ $\left.\mathrm{t}_{(102)}=-1,586 ; \mathrm{p}>0.05\right]$. According to these findings, it can be said that the spatial thinking skills of the students in the Experimental Groups and Control Groups before the application are equivalent to each other.

Table 7

T-Test Results for the Difference of the STST Pre-Test Post-Test Success Scores of Primary School Students in Grade 4 According To the Experimental Groups

\begin{tabular}{|c|c|c|c|c|c|c|c|}
\hline Groups & & $N$ & $\overline{\boldsymbol{X}}$ & $S$ & $s d$ & $t$ & $p$ \\
\hline \multirow{2}{*}{$\begin{array}{l}\text { Experiment } \\
1\end{array}$} & Pre test & 28 & 9.39 & 3,823 & 54 & \multirow[t]{2}{*}{$-8,027$} & \multirow[t]{2}{*}{, $000^{*}$} \\
\hline & Post test & 28 & 18.46 & 4,598 & & & \\
\hline \multirow[b]{2}{*}{$\begin{array}{l}\text { Experiment } \\
2\end{array}$} & Pre test & 23 & 8,60 & 2,606 & 44 & \multirow[t]{2}{*}{$-6,773$} & \multirow[t]{2}{*}{, $000^{*}$} \\
\hline & Post test & 23 & 16.34 & 4,820 & & & \\
\hline \multirow{2}{*}{$\begin{array}{l}\text { Experiment } \\
\text { Total }\end{array}$} & Pre test & 56 & 9,89 & 4,384 & 105 & \multirow{2}{*}{$-8,605$} & \multirow[t]{2}{*}{, $000^{*}$} \\
\hline & Post test & 51 & 17.50 & 4,772 & & & \\
\hline
\end{tabular}

According to Table 7, a significant difference in favor of post-test achievement scores was observed between the mean scores of spatial thinking skill test pre-test and post-test scores of Experimental Group 1 and Experimental Group 2 (Experiment Group 1: ( $\mathrm{t}(54)=-8,027 ; \mathrm{p}<0)$ 05]; Experiment Group 2: [t $(44)=--$ $6.773 ; \mathrm{p}<0.05]$. There was also a significant difference in favor of the post-test achievement scores between the pre-test and post-test spatial thinking skill test achievement scores of the whole Experimental Group [t $(105)=-8,605 ; \mathrm{p}<0.05]$. According to these findings, it can be said that the spatial thinking skills of the Experimental Groups were higher after the application compared to the preapplication. In other words, it increases the spatial thinking skills of the students in the Experimental Group for the learning area of "People, Places and Environments" in the Social Studies course, when it is taught with orienteering activities.

Table 8

T-Test Results for the Difference in STST Pre-Test-Post-Test Achievement Scores of Primary School Students in Grade 4 Compared To Control Groups

\begin{tabular}{|c|c|c|c|c|c|c|c|}
\hline Groups & & $N$ & $\bar{X}$ & $S$ & $s d$ & $t$ & $p$ \\
\hline \multirow[b]{2}{*}{ Control 1} & Pre -test & 28 & 11,28 & 3,720 & 54 & \multirow[t]{2}{*}{$-3,029$} & \multirow[t]{2}{*}{, $004^{*}$} \\
\hline & Post-test & 28 & 14.75 & 4,773 & & & \\
\hline \multirow[b]{2}{*}{ Control 2} & Pre-test & 25 & 8,80 & 2,943 & 48 & \multirow[t]{2}{*}{$-4,068$} & \multirow[t]{2}{*}{, $000^{*}$} \\
\hline & Post-test & 25 & 12,80 & 3,937 & & & \\
\hline \multirow{2}{*}{$\begin{array}{l}\text { Control } \\
\text { Total }\end{array}$} & Pre-test & 53 & 10.11 & 3,571 & 104 & \multirow[t]{2}{*}{$-4,732$} & \multirow[t]{2}{*}{, $000^{*}$} \\
\hline & Post-test & 53 & 13.83 & 4,466 & & & \\
\hline
\end{tabular}

According to Table 8, a significant difference was found between the STST pretest-post-test achievement scores of Control Group 1 and Control Group 2. The results were in favor of post-test scores (Control Group 1: $\left(\mathrm{t}_{(54)}=-3.029 ; \mathrm{p}<0,05\right]$; Control Group2: $\left.\mathrm{t}_{(48)}=--4,068 ; \mathrm{p}<0,05\right]$. There was also a significant difference in 
Yiğit, T.; Karatekin, K.(2021). The Effect of Orienteering Applications on Students' Spatial Thinking...

favor of the post-test success scores between the pre-test and post-test spatial thinking skill test success scores of the whole Control Group [t $(104)=-4,732 ; p$ $<0.05]$. According to these findings, it can be said that the spatial thinking skills of the Control Groups were higher after the application compared to the preapplication. In other words, the program-based Social Studies lessons will increase the spatial thinking skills of the students in the Control Group in the learning area of "People, Places and Environments".

Table 9

One-Way Analysis Of Variance for the Difference in STST Post-Test Success Scores of Primary School Students in Grade 4 According To the Groups

\begin{tabular}{lllllll}
\hline & $K T$ & $S d$ & $K O$ & $F$ & $P$ & $\begin{array}{l}\text { Difference } \\
\text { Tukey }\end{array}$ \\
\hline Between Groups & 458,684 & 3 & 152,895 & 7,388 &, $000^{*}$ & $1-3$ \\
$1-4$ \\
In Groups & 2069,432 & 100 & 20,694 & & & $2-4$ \\
\hline Total & 2528,115 & 103 & & & & \\
\hline
\end{tabular}

According to Table 9, a one-way analysis of variance (ANOVA) was conducted to determine whether there is a significant difference between the STST post-test success scores of primary school students in Grade 4 in the Experimental Groups and Control Groups. As a result of the analysis, a significant difference was observed between the groups $[\mathrm{F}(3-100)=7.388 ; \mathrm{p}<0.05]$. According to the results of Tukey test conducted to determine which groups the difference is as follows: the average of STST post-test success scores of students in Experimental Group 1 was $(\overline{\mathbf{X}}=11,28)$; the average of STST post-test success scores of students in Control Group 1 was ( $\bar{X}=8,60)$; and Control Group 2 students' STST post-test showed a significant difference was found in favor of Experiment Group 1 students between the average achievement scores $(\overline{\mathbf{X}}=8.80)$. Again, a significant difference was found between the Experimental Group 2 students' STST post-test success scores $(\overline{\mathbf{X}}=11.28)$ and the Control Group 2 students' STST post-test success scores $(\overline{\mathbf{X}}=11.28)$, the results were in favor of the Experimental Group 2 students. Although there is no significant difference between the STST post-test scores of the Experimental Group 2 students and the STST post-test success scores of the Control Group 1 students, it is seen that the STST post-test mean scores of the Experimental Group 2 are higher than the Control Group 1. According to these findings, it can be said that the spatial thinking skills of the Experimental Group 1 and Experimental Group 2 were higher than Control Group 1 and Control Group 2 .

Table 10

Descriptive Data-On STST Post-Test Success Scores

\begin{tabular}{lllll}
\hline Groups & Group Names & $N$ & $\bar{X}$ & Ss \\
\hline 1 & Experiment 1 post-test & 28 & 18.46 & 4,598 \\
\hline 2 & Experiment 2 post-test & 23 & 16.34 & 4,820 \\
\hline 3 & Control 1 post-test & 28 & 14.75 & 4,773 \\
\hline 4 & Control 2 post-test & 25 & 12,80 & 3,937 \\
\hline Total & & 104 & 15.63 & 4,954 \\
\hline
\end{tabular}


Table 11

T-Test Results For the Difference of the STST Post-Test Success Scores of Primary School Students in Grade 4 Compared To the Experimental and Control Groups

\begin{tabular}{lllllll}
\hline School Type & $N$ & $\bar{X}$ & $S$ & $s d$ & $t$ & $p$ \\
\hline $\begin{array}{l}\text { Experimental } \\
\text { group }\end{array}$ & 51 & 17,53 & 4,729 & 102 & 4,228 &, $000^{*}$ \\
\hline Control group & 53 & 13.73 & 4,450 & & & \\
\hline
\end{tabular}

When all Experimental Groups and Control Groups were considered together, there was a significant difference between the STST posttest success scores of the primary school students in Grade 4 between the Experimental and Control groups. [ $\left.\mathrm{t}_{(102)}=-2,228 ; \mathrm{p}<0.05\right]$. According to this finding, it can be said that the spatial thinking skills of students in the Experimental Group where the lesson was taught with orienteering practices, was higher than the student in the Control Group where the lesson was taught based on the program. In other words, the teaching of orienteering applications in lessons for "People, Places and Environments" learning area in Social Studies does increase the spatial thinking skills ofstudents more than it is based on the program.

Table 12

T-test results for the difference in STST post-test success scores of primary school students in Grade 4 by gender

\begin{tabular}{lllllll}
\hline Gender & $N$ & $\bar{X}$ & $s$ & $s d$ & $t$ & $p$ \\
\hline Female & 48 & 16,52 & 5,299 & 102 & 1.704 &, 091 \\
\cline { 1 - 4 } Male & 56 & 14.87 & 4,548 & & \\
\hline
\end{tabular}

According to Table 13, the average STST post-test success scores of primary school students in Grade 4 did not show a significant difference according to gender $\left[\mathrm{t}_{(102)}=-1,704 ; \mathrm{p}>0.05\right]$. Although female students' STST post-test success scores were higher than for male students, it was observed in this study that a gender variable had no effect on spatial thinking skills.

\section{Result and Discussion}

In this title, the data obtained as a result of the study and the results obtained for the sub-problems as a result of the analysis were discussed.

"Do the pre-test success scores of the Spatial Thinking Skills Test from the participating students differ according to the variable of the group (experiment 1 , experiment 2, control 1, control 2)?" As a result of the analysis of the subproblem, a significant difference was observed between the groups. According to the analysis of results: There was a significant difference in favor of Control group 1. The difference was found between the STST pre-test success score averages between students in Control Group 1 and Experimental Group 2 group and Control Group 2. According to this result, it was seen that before the application, the spatial thinking skills of the Experimental Group 1, Experimental Group 2 and Control 
Group 2 were equivalent to each other, and the Control Group 1 students had higher spatial thinking skills than the other groups.

"Does the Spatial Thinking Skill Test success scores of the Experimental Group students participating in the study differ according to the measurements (pre-testpost-test)?" regarding the sub problem?" There was a significant difference between the STST pre-test and post-test success scores between students in the Experimental Group 1 and Experimental Group 2, the results were in favor of the post-test success scores. A significant difference was found between the pre-testpost-test STST success scores of all Experimental Groups in favor of the post-test success scores. According to these findings, it can be said that the spatial thinking skills of the Experimental Groups were higher than before the application. These results are similar to the results of the work by Notarnicola et al. (2012). In addition, this result overlaps with the statements of Karaca (2008), which stated that orienteering practices positively affect students' learning levels.

"Do the Spatial Thinking Skill Test success scores of the Control Group students participating in the study differ according to the measurements (pre-test-posttest)?" regarding the sub problem?" There was a significant difference between the STST pre-test post-test success scores between students in Control Group 1 and Control Group 2, the results were in favor of the post-test scores. A significant difference was found between the pre-test post-test STST success scores of all control groups in favor of the post-test scores. According to these findings, it can be said that the spatial thinking skills of the control groups were higher than before the application.

"Do the post-test success scores of the Spatial Thinking Skill Test of the participating students differ according to the group (experiment and control) variable?" In order to determine whether there is a significant difference regarding the sub-problem, STST was applied to the Experimental Groups and Control Groups as a post-test at the end of different teaching practices. According to the analysis results based on the post-test results, a significant difference was found between the STST average success scores for students in the Experimental Groups and the Control Groups. Considering the STST post-test average success scores, it was observed that there was an increase in the spatial thinking skills of students in both the Experimental Groups and the Control Groups. However, when looking at the average success scores, it was seen that the increase was more in favor of the Experimental Groups. In other words, the teaching of lessons for the "People, Places and Environments" learning area in Social Studies with the inclusion of orienteering applications does increase the spatial thinking skills of the students. Spatial thinking skills of students in the Social Studies course, when it is taught with orienteering applications and orienteering practices did contribute positively to the development of spatial visualization, spatial orientation and spatial relations skills.

It is thought that orienteering, which is a teaching technique within the method of teaching with games, is effective for increasingthe STST average achievement scores in the Experimental Groups; this will make a significant difference compared to the students in the Control Groups. Such results are also supported by 
the literatüre: that education with play is more effective than traditional methods (Koçyiğit, Tuğluk \& Kök, 2007, Torun \& Duran, 2014, Özyürek \& Çavuş, 2016, Uzuner, 2019). A study conducted by Yıldız \& Şimșek (2020) about educational games states they makes the lesson and the subject interesting, it increases student desire to learn with the sense of curiosity and discovery, and it also reduces the level of anxiety and enables healthy thinking. The fact that Kaya \& Elgün (2015) state that educational games are effective in students' focusing on the subject, and for increasing their motivation and permanence of their learning does support our research result. Educational games offer children opportunities to learn by doing and by experience, as well as help them gain new skills and functions. Koçyiğit, Tuğluk \& Kök (2007, p.339) use the following expressions about the game: "Most of the time, the child tries the skills of adult life in the game and turns the behaviors they see from the family, friend group, teacher and other adults into a skill by repeating them in the game".

The explanations above show that the educational use of the game increases the effectiveness of teaching and makes it easier. It has been revealed that orienteering, which is known as a type of sport, can be used in lessonsso that orienteering practices have positive effects on teaching students various subjects and gaining skills (Özcan, 2006, Karaca, 2008, Tanrıkulu, 2011, Vukadinović, Juhas \& Kozoderović, 2015, Uzuner, 2019). However, it has been seen in the literature that orienteering also has positive effects on the development of spatial thinking skills together with our research results. Natarnicola et al. (2012), Guzman, Pablos \& Pablos (2008) and Avcl (2013) have all conducted studies to show lessons taught with orienteering practices contribute to the development of students' spatial thinking skills. Again, Pouya, Demir \& Demirel (2017) express the effects of orientation on development of spatial thinking skills including geographical information as follows:

In the orienteering practice in which Geography skills are used, participants can use maps (read symbols and scales, read distances, landforms), find directions on the map and in the field, determine their location, use compass, prepare field studies, practice with geographic information, evaluate information, real life problems and It has been determined that it has increased many skills such as dealing with their situation (p. 616).

From these explanations, it is seen that orienteering practices are an effective teaching technique in gaining spatial thinking skills, which are also a geographical skill. The increase in the STST average success scores of students in the Control Group in the post-test suggest the activities in the textbook on the subject are related to the direction finding, sketch, natural and human elements in the textbook and student workbook. As a matter of fact, Karatekin (2006) stated that there may be increases in Control Groups as well, and it is effective to deal with the subject based on the activities included in the curriculum.

In our study, "Does the gender variable have any effect on the Spatial Thinking Skill Test post-test success scores of students in the Experimental Groups and Control Groups?" According to the data obtained from STST results held before and after the application, the STST post-test success point averages of primary school in Grade 4 did not show a significant difference according to gender. In this case, Öcal (2007) results do overlaps with the results of the study, however, the work 
of Merç (2011) does not coincide with the results of the current study. In addition, a study conducted by Hart (1979) suggests spatial thinking skills in male students are more successful than for female students, therefore such results do not coincide with the results of the current study. Although female students' STST post-test mean scores were higher than male students, a gender variable had no effect on spatial thinking skills in this study.

The result of the research is that orienteering applications can be used in Social Studies courses and with other studies (Karaca, 2008, Tanrıkulu, 2011, Avcl, 2013, Di Tore, Corona \& Sibılo, 2015, Kobayashi, 2019, Uzuner, 2019). Furthermore, it has been observed that orienteering is a game-based teaching technique that increases the educational achievement of students.

\section{Suggestions}

- Orienteering can be used as a new teaching technique in Social Studies lesson since it is an activity that enables learning by doing, develops multi-faceted thinking, and allows fort he transference of skills to daily life.

- Orienteering practices can be used more frequently during in-service teacher training.

- Orienteering is a sport that increases the physical and mental skills of students, therefore, it can be established as a club in schools and orienteering competitions can be organized during the semester.

- This image of a Social Studies course as verbal and rote-learning types of lessons in the eyes of the students, can be changed by introducing orienteering activities to make the lessons more enjoyable.

- The physical conditions of schools can be made more suitable within the scope of orienteering practices. School gardens, where students can safely run and play, are very important for orienteering practices.

- The processing time in the curriculum for Social Studies lessons about the "People, Places and Environments" learning area can be changed because the processing of skill acquisitions in this learning area with orienteering applications is generally based on outdoor activities. However, in Turkey where the sun is scarce, the weather is low and the winter conditions are experienced in the program, it is difficult to teach this learning area with orienteering practices.

\section{References}

Ablak, S. (2019). Sosyal bilgilerde beceri eğitimi. B. Aksoy, B. Akbaba ve B. Kılcan (Ed.) içinde, Mekânı algılama (s. 413-430). Ankara: Pegem Akademi Yayıncılık.

Akgül, N. İ. (2006). The methods used by classroom teachers in social studies course and the problems they encountered (Niğde Province Example) (Yayımlanmamış yüksek lisans tezi). Niğde Üniversitesi Sosyal Bilimler Enstitüsü, Niğde.

Akman, K. (2017). Investigation of orienteer high-schoolers' motivation levels in terms of different variables (Yayımlanmamış yüksek lisans tezi). Atatürk Üniversitesi Eğitim Bilimleri Enstitüsü, Erzurum. 
Akmehmetoğlu, H. (2014). The problems encountered by Social Sciences teachers in Social Sciences teaching (Sample of Kastamonu province) (Yayımlanmamış yüksek lisans tezi). Kastamonu Üniversitesi Sosyal Bilimler Enstitüsü, Kastamonu.

Aktürk V., Yazıcı H. \& Bulut R. (2013). The effects of the use of animations and digital maps in social studies on students' spatial perception skills. Marmara Coğrafya Dergisi, 28, 1-17.

Aktürk, V. (2012). The effects of using animation and digital map for students? capabilities to perceive the space in social studies lesson (Yayımlanmamış yüksek lisans tezi). Afyon Kocatepe Üniversitesi Sosyal Bilimler Enstitüsü, Afyon.

Aladă̆, S. (2015). Sosyal bilgiler öğretimi. Ramazan Sever (Ed.) içinde, Sosyal bilgiler ögretiminde beceriler (s. 307-348). Ankara: Nobel Akademi Yayıncılık.

Alataş, F. (2008). The soft sciences course of 4th and 5th grades in primary school (Yayımlanmamış yüksek lisans tezi). Dokuz Eylül Üniversitesi Eğitim Bilimleri Enstitüsü, İzmir.

Ata, B. (2015). Sosyal bilgiler öğretimi: demokratik vatandașlık eğitimi. Cemil Öztürk (Ed.) içinde, Sosyal bilgiler öğretim programı (s. 33-47). Ankara: Pegem Akademi Yayıncılık.

Ateş, A. (2007). A research on the basic problems that the orienteers face in Turkey (Yayımlanmamış yüksek lisans tezi). Gazi Üniversitesi Eğitim Bilimleri Enstitüsü, Ankara.

Avcl, M. (2013). Geography students' views on the use of orienteering activity in geography education (Yayımlanmamış yüksek lisans tezi). Gazi Üniversitesi Eğitim Bilimleri Enstitüsü, Ankara.

Baloğlu Uğurlu, N., \& Aladağ, E. (2015). The placing of spatial thinking in Turkish social studies education and social studies teachers' opinion about this issue. Marmara Coğrafya Dergisi, 32, 22-42.

Büyüköztürk, Ş. (2007). Sosyal bilimler için veri analizi el kitabı. Ankara: Pegem Akademi Yayıncilık.

Çepni, S. (2014). Araştırma ve proje çalışmalarına giriş. (7. Basım). Trabzon: Celepler Matbaacilı.

Demirci, A. (2008). Coğrafya öğretiminde yöntem ve yaklaşımlar. R. Özey ve A. Demirci (Ed.) içinde, Coğrafyayı yeniden keşfetmek (1-16). İstanbul: Aktif Yayınevi.

Di Tore, P. A., Corona, F., \& Sibilio, M. (2015). Orienteering: Spatial Navigation Strategies and Cognitive Processes. Journal of Human Sport and Exercise, 10(1), 507-514.

Doğan, C. (2004). Classroom teachers' views on lessons and their preferred teaching methods: Sample of Istanbul province. Türk Ë̆itim Bilimleri Dergisi, 2 (2), 193-203.

Ekiz, D. (2013). Bilimsel araştırma yöntemleri. Ankara: Anı Yayıncılık.

Emekli, G. (2006). Geography, culture and tourism: Cultural tourism. Ege Coğrafya Dergisi, 15, 51-59.

Gelbal, S. (2013). Ölçme ve değerlendirme. Eskişehir: Anadolu Üniversitesi Açık Öğretim Fakültesi Yayınları.

Gençtürk, E. (2013). Sosyal bilgiler için çoklu okuryazarlık. K. Karatekin ve E. Gençtürk (Ed.) içinde, Coğrafya okuryazarlığı (s. 24-42). Ankara: Pegem Akademi Yayıncılık.

Golledge, R. G., Marsh, M. \& Battersby, S. (2008). Matching geospatial concepts with geographic educational needs. Geographical Research, 46(1), 85-98. 
Yiğit, T; Karatekin, K.(2021). The Effect of Orienteering Applications on Students' Spatial Thinking...

Guzmán, J. F., Pablos, A. M., \& Pablos, C. (2008). Perceptual-cognitive skills and performance in orienteering. Perceptual and motor skills, 107(1), 159-164.

Hart, R. (1979). Children's experience of place. Newyork: Irvington Publishers.

Huynh, N. T. (2009). The role of geospatial thinking and geographic skills in effective problem solving with gis: $\mathrm{K}$-16 education (Unpublished doctoral dissertation). Wilfrid Laurier University, Ontario.

Jo, I. (2011). Fostering a spatially literate generation: Explicit instruction in spatial thinking for preservice teachers (Unpublished doctoral dissertation). Texas A\&M University, Texas.

Kan, C.. (2006). The pursuit of effectıve instruction of social studies course. Kastamonu Eğitim Dergisi, 14(2), 537-544.

Karaca, F. (2008). Function of orienteering applications on primary school's program (Yayımlanmamış yüksek lisans tezi). Gazi Üniversitesi Sağlık Bilimleri Enstitüsü, Ankara.

Karatekin, K. (2006). The effect of teaching the subject of direction and finding methods according to multiple intelligence theory on student's success at the 4th class of primary school (Yayınlanmamış yüksek lisans tezi). Gazi Üniversitesi Eğitim Bilimleri Enstitüsü, Ankara.

Karatekin, K., Sönmez, Ö. F., \& Kuş, Z. (2010). Facing problems and teachers' opinions about the practising of teaching activities prepared according to multiple intelligence. Türkiye Sosyal Araștırmalar Dergisi, 14(2), 139-154.

Kaya, S., \& Elgün, A. (2015). The influence of instructıonal games in science teaching on prımary students' achıvement. Kastamonu Eğitim Dergisi, 23(1), 329-342.

Kim, M. (2011). Effects of a gis course on three components of spatial literacy (Unpublished doctoral dissertation). Texas A\&M University, Texas.

Kobayashi, T. (2019, July). Orienteering in geography education in japanese high school. Paper Presented at the 29th International Cartographic Conference (ICC 2019), Tokyo, Japan.

Koçyiğit, S., Tuğluk, M. N., \& Kök, M. (2007). Play as educational activity in the child's development process. Atatürk Üniversitesi Kazım Karabekir Eğitim Fakültesi Dergisi, 16, 324-342.

Köşker, N. (2012). Thoughts of prospectıve class teachers on theırspatıal cognitıve adequacy. Zeitschrift für die Welt der Türken/Journal of World of Turks, 4(3), 161173.

Lee, J. W. (2005). Effect of gis learning on spatial ability (Unpublished doctoral dissertation). Texas A\&M University, Texas.

Lee, J., \& Bednarz, R. (2009). Effect of GIS learning on spatial thinking. Journal of Geography in Higher Education, 33(2), 183-198.

Lee, J., \& Bednarz, R. (2012). Components of spatial thinking: Evidence from a spatial thinking ability test. Journal of Geography, 111(1), 15-26.

Merç, A. (2011). Spatial cognition and map-reading skills of students studying social studies education and pre-school education (Yayımlanmamış yüksek lisans tezi). Adnan Menderes Üniversitesi Sosyal Bilimler Enstitüsü, Aydın. 
Merç, A. (2017). The effectiveness of Google Earth in the acquisition of spatial perception ability in social studies courses (Yayımlanmamış doktora tezi). Anadolu Üniversitesi Eğitim Bilimleri Enstitüsü, Eskișehir.

Ministry of National Education (2018). 2018 Social Studies Lesson Curriculum (Primary and Secondary School 4, 5, 6 and 7 grades). Retrieved from https://mufredat.meb.gov.tr/Dosyalar/201812103847686SOSYAL\%20B\%C4\%B0L G\%C4\%B0LER\%20\%C3\%96\%C4\%9ERET\%C4\%B0M\%20PROGRAMI\%20.pdf

Mohan, L., Mohan, A., \& Uttal, D. (2014). Research on thinking and learning with maps and geospatial technologies. Learning progressions for maps, geospatial technology and spatial thinking: A research handbook. Washington, DC: Association of American Geographers, 9-21.

Mutluer, C. (2013). Social studies teachers' views about the skills in social studies programs (Izmir menemen sample). International Periodical For the Languages, Literature and History of Turkish or Turkic Volume 8/7 Summer 2013, 355-362.

Namal, R. (2019). The development of graph drawing ang interpretation skills in social studies teaching (Yayımlanmamış doktora tezi). Gazi Üniversitesi Eğitim Bilimleri Enstitüsü, Ankara.

Notarnicola, A., Vicenti, G., Tafuri, S., Fischetti, F., Laricchia, L., Guastamacchia, R., \& Moretti, B. (2012). Improved mental representation of space in beginner orienteers. Perceptual and motor skills, 114(1), 250-260.

Öcal, A. (2007). Inquiring 6. grades student's spatial cognition skills in elementary school social studies course (Yayımlanmamış doktora tezi). Gazi Üniversitesi Eğitim Bilimleri Enstitüsü, Ankara.

Öcal, A. (2009). Sosyal bilgiler öğretiminde yeni yaklaşımlar-1. R. Turan, A. M. Sünbül ve H. Akdağ (Ed.) içinde, Sosyal bilgiler dersinde mekânı algılama becerisini yeniden düşünmek (s.263-278). Ankara: Pegem Akademi Yayıncllık.

Özcan, F. (2006). Examination of orieenterlng sport on the effect of mathematical - logical and social individual attitudes of college students (Yayımlanmamış yüksek lisans tezi). Dumlupınar Üniversitesi Sosyal Bilimler Enstitüsü, Kütahya.

Özçelik, D. A. (2010). Ölçme ve değerlendirme. Ankara: Pegem Akademi.

Özdemir, A. A. (2011). The effect of spatial skill education program on spatial skills of preschool children's (Yayımlanmamış doktora tezi). Marmara Üniversitesi Ë̆itim Bilimleri Enstitüsü, İstanbul.

Özyürek, A., \& Çavuş, Z. S. (2016). Examination of the status of primary school teachers whether or not they use game-based teaching techniques. Kastamonu Education Journal, 24(5), 2157.

Pouya, S., Demir, S., \& Demirel, Ö. (2017). Orienteering plays for disabled children. Kastamonu Üniversitesi Orman Fakültesi Dergisi, 17(4), 608-618.

Safi, H. (2010). Teachers' opinions about the spatial cognition skills (Yayımlanmamış yüksek lisans tezi). Marmara Üniversitesi Eğitim Bilimleri Enstitüsü, İstanbul.

Şahin, D., \& Güven, S. (2016). The opinions of primary school teachers on teaching methods and techniques in science and technology, science of life courses and social studies. Online Fen Eğitimi Dergisi, 1(1), 42-59.

Selanik Ay, T., \& Yavuz, Ü. (2016). The implementations classroom teachers use in order to reinforce literacy skills in social studies classes. Anadolu Journal of Educational Sciences International, 6(2), 31-63. 
Yiğit, T.; Karatekin, K.(2021). The Effect of Orienteering Applications on Students' Spatial Thinking...

Şimşek, S. \& Öztürk M. (2019). Sosyal bilgiler eğitimine giriş. Süleyman İnan (Ed.) içinde, Beceriler (s. 193-224). Ankara: Anı Yayıncılık.

Sönmez, F. (2019). The effect of geographical information systems (Gis) based on social studies teaching on spatial thinking skills (Yayımlanmamış yüksek lisans tezi). Trabzon Üniversitesi Lisansüstü Eğitim Enstitüsü, Trabzon.

Sönmez, Ö. F. (2010). Map skills in primary school social studies education (Yayımlanmamış doktora tezi). Gazi Üniversitesi Eğitim Bilimleri Enstitüsü, Ankara.

Tanrıkulu, M. (2011). A dıfferent usıng area of map and compass orıenteerıng. Milli Ĕgitim Dergisi, 41(191), 120-126.

Taş, H. İ. (2006). The importance of vitualizations in geographic education: An educational aproaches to spatial context. Doğu Coğrafya Dergisi, 16, 211-238.

Taşdemir, A. (2016). Problems encountered in the teaching of social studies teachers by social studies in socio-economically disadvantaged regions (Sample of Ağrı provience) (Yayımlanmamış doktora tezi). Ağrı İbrahim Çeçen Üniversitesi Sosyal Bilimler Enstitüsü, Ağrl.

Torun, F., \& Duran, H. (2014). Effect of game method on success, permanence and attitude In chıldren's rıghts educatıon. Adıyaman Üniversitesi Sosyal Bilimler Dergisi, 7(16), 418-448.

Tümertekin, E. \& Özgüç, N. (2019). Beșeri coğrafya: İnsan, kültür ve mekân. (18. Basım). İstanbul: Çantay Kitabevi.

Tuna, F., \& Balcl, A. (2013). The effects of orienteering on prospective geography teachers' self-efficacy perceptions. Marmara Coğrafya Dergisi, 27, 1- 14.

Turan, R. (2018). A general evaluation on 2017 primary and middle school social studies currıculum. Diyalektolog Ulusal Sosyal Bilimler Dergisi,19,295-328.

Turgut, M. F. \& Baykul, Y. (2014). Eğitimde ölçme ve değerlendirme. Ankara: Pegem Akademi.

Türker, A. (2019). Sosyal bilgilerde beceri eğitimi. B. Aksoy, B. Akbaba ve B. Kılcan (Ed.) içinde, Değisşim ve sürekliliği algılama (s.53-66). Ankara: Pegem Akademi

Ünlü, M. (2011). The level of realizing geographical skills in geography lessons. Kuram ve Uygulamada Eğitim Bilimleri. 11(4), 2155-2172.

Uzuner, F. G. (2019). An investigation of the effects of orienteering on the development of primary school students' math problem-solving skills (Yayımlanmamıs doktora tezi). Trabzon Üniversitesi Lisansüstü Eğitim Enstitüsü, Trabzon.

Vukadinović, N., Juhas, I. \& Kozoderović, J. (2015). Orienteering section as a form of extracurricular activities in physical education. Fizička Kultura, 69(1), 59-69.

Yıldız ve Şimşek (2020) The effect of educational game, readıng-writıng-game, and reading-writıng-applıcation methods on elımınatıng learnıng problems. Balıkesir University The Journal of Social Sciences Institute, 23 (43), 87-117.

\section{Biographical Statements}

Turan Yí̆̌it is a classroom teacher at Kastamonu Gazipaşa Primary School. He has a master's thesis on social studies education.

Kadir KARATEKIN is a professor in the department of classroom education at the University of Kastamonu. His research interests are social studies education, encironmental education, value education. . 